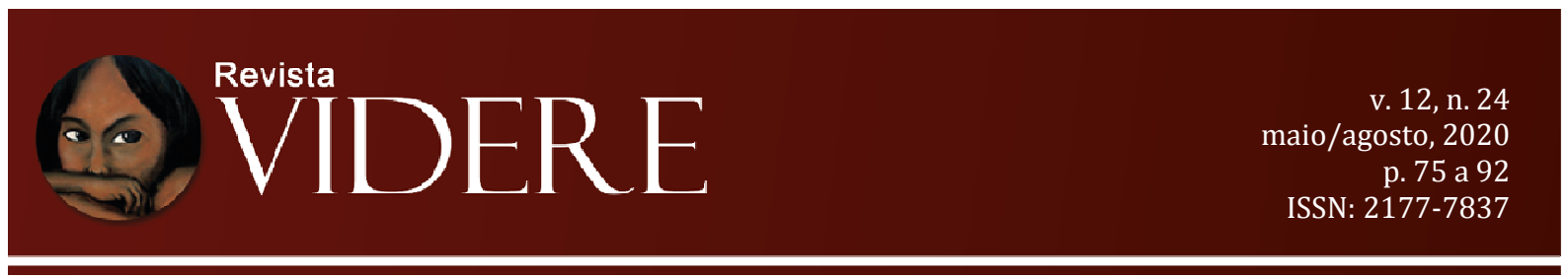

\title{
A CAPTURA DA DEMOCRACIA PELA POLÍTICA DA AUSTERIDADE: A POLÍTICA ENTRE OS CIFRÕES
}

\section{THE CAPTURE OF DEMOCRACY BY THE AUSTERITY POLICY: POLITICS AMONG THE DOLLAR SIGNS}

\author{
Diogo Bacha e Silva \\ Doutor em Direito pela Universidade Federal do \\ Rio de Janeiro (UFRJ), Brasil \\ E-mail: diogobacha@ig.com.br \\ OrcID: http://orcid.org/0000-0001-9748-0714
}

\author{
José Ribas Vieira \\ Doutor em Direito pela Universidade Federal do \\ Rio de Janeiro (UFRJ)), Brasil \\ Professor da Pontifícia Universidade Católica do \\ Rio de Janeiro (PUCRIO), Brasil \\ E-mail: jribas@puc-rio.br \\ OrcID: https://orcid.org/0000-0002-0845-8273 \\ Fernanda Lage Dantas \\ Doutoranda em Teorias da Decisão e da \\ Interpretação e Justiça (UFRJ), Brasil \\ E-mail: fernandalage@hotmail.com \\ OrcID: https://orcid.org/0000-0003-1104-7173
}

RESUMO: O presente artigo pretende analisar a política de austeridade como fenômeno político-econômico de um projeto de poder de cooptação da própria democracia. Através de uma análise crítico-reflexiva sobre os fenômenos sociais e políticos ocorridos a partir de 2013, o trabalho explora em que medida a política de austeridade consegue se firmar a partir de uma ruptura político-institucional. No entanto, a política de austeridade só pode ser combatida com um projeto democrático-radical. A originalidade consiste em dialogar no atual momento o déficit democrático com a política de austeridade.

Palavras-chave: Política de Austeridade; democracia agonística; Estado Social.

\begin{abstract}
The present article intends to analyze the austerity policy as a political-economic phenomenon of a project of power to co-opt democracy itself. Through a critical-reflective analysis of the social and political phenomena that occurred since 2013, the work explores the extent to which austerity policy is able to establish itself from a political-institutional rupture. However, the austerity policy can only be countered with a radical-democratic project. The originality consists in dialoguing the democratic deficit with the austerity policy at the present time.
\end{abstract}

Keywords: Austerity Policy; agonistic democracy; Welfare State. 


\section{Introdução}

Vivemos em um conturbado momento político na realidade brasileira na qual as instituições são cooptadas por um projeto de poder. Qual seria esse projeto de poder? Qual fundamento o sustenta? A quem tal poder beneficiaria? É um projeto local ou universal? O projeto tem condições de se tornar universal?

Obviamente, qualquer projeto de poder hegemônico precisa necessariamente de fundamentos políticos-teóricos e, efetivamente, o desmonte de um projeto democrático. Os antecedentes para a consolidação do projeto de poder que vamos continuar no presente trabalho é a ruptura político-institucional com o projeto constituinte de democratização de nossa sociedade realizado pela Constituição de 1988.

O poder é exercido sempre em benefício de uma ordem, não há como se conceber algo como um poder puro, já que o zoon politikon impele que há uma miscelânea do homem sobre o homem. Mesmo, por exemplo, a democracia liberal do século XVIII e XIX teve como condão permitir a ascensão burguesa. Esse projeto universalizante possibilitou a consolidação do capitalismo como ordem econômica universal e imperiosa.

Para dizer com Marx, autor central deste trabalho, a história se repete a primeira vez como tragédia e a segunda vez como farsa. Mais uma vez, portanto, assistimos um projeto político-econômico de dominação que, embora ofereça novas roupagens e novos problemas, a finalidade seria beneficiar o capital hegemônico.

Pensar a política, então, é pensar como se desenvolve as relações econômicas e de poder. Contanto com novos instrumentos de dominação, tais como mass media, instituições estatais, o olhar sobre a política não pode ser separado da economia e dos interesses de uma sociedade eminentemente capitalista.

A política, assim, é utilizada como meio e como fim. Uma relação contraditória e paradoxal, meio e fim, instrumento e objetivo. A política é capturada como meio e como fim, numa relação impossível, uma relação que deve ser descontruída, re-pensada, pensada novamente, utilizando-se pensamentos novos e antigos, clássicos e modernos são utilizados como relação não-linear para fundamentar novas roupagens de velhas práticas políticas de dominação.

A saída para a política cooptada só pode se dar pela própria política.

\section{Sobre a relação entre economia e política: uma nova velha relação ou uma velha nova relação?}


Entre política e economia há uma relação nem tão nova, nem tão velha. Vale dizer, uma relação necessária que escapa à apropriação temporal como um evento único e indefinível. Há, na verdade, no pensar desta relação, um desvelamento (Aletheia) como um acontecimento (Eirignis) (HEIDEGGER, 2012; HEIDEGGER, 1999). A cada verdade há uma essência falível, provisória, abrindo a possibilidade de novos conhecimentos (CRUZ, 2011). Nenhum tempo entendido com um caráter ôntico, um tempo que se divide em passado, presente e futuro, poderá explicar e revelar a relação entre política e economia.

Já na antiga relação entre filosofia e política, cujas origens remontam ao julgamento de Sócrates e à sua condenação, que começa com um ódio entre os políticos ateniense e a busca pela verdade de $\operatorname{Sócrates}^{33}$, a política se imiscui no pensar e se oferece como possibilidade de detentora da verdade como saber para ser a verdade do poder $^{34}$. Mas, ao mesmo tempo, muito embora os filósofos fossem apenas expectadores do mundo, enquanto sujeitos da Theoreîn e os políticos fossem sujeitos da Pràktiké, essa isenção era apenas um modo de encobrir uma relação que nasce paradoxal.

É que a pólis enquanto comunidade política só ganha sentido se confrontada com a oíkos. De um lado, a comunidade política é a associação humana mais alta dentre todas as outras, abarcando as outras, e perseguindo, por conseguinte, o valor mais alto de todas. No entanto, para se compreender a pólis é necessário decompor seus elementos, como já Aristóteles (2010, p. 53) ensinava. A primeira associação é aquela representada pela família, onde se liga homem e mulher, senhor e escravo. A oíkos é o lugar do cotidiano e não dos valores mais altos. Neste espaço estão imbricados o chefe, a mulher e o escravo, cada qual atendendo uma natureza.

A economia é o espaço da oíkos, ela é o governo doméstico, onde são utilizados instrumentos para a consecução das finalidades do serviço doméstico, sejam seres animados ou inanimados, consoante alertava Aristóteles (2010, p.58). A economia e sua ciência teriam por objetivo a posse, a relação de domínio que se exerce sobre as coisas. Ela deve servir de base para o chefe da família e também das cidades.

\footnotetext{
${ }^{33}$ Em passagem importante, Sócrates Foi a um dos homens detentores de sabedoria. Um político que parecia ser para muitos e para ele mesmo um sábio. Sócrates diz que tentou demonstrar para o mesmo que ele parecia ser sábio sem o ser. Daí veio o ódio dele contra ele. Diz então: “[...] eu sou mais sábio do que esse homem, pois que, ao contrário, nenhum de nós sabe nada do belo e de bom, mas aquele homem acredita saber alguma coisa, sem sabe-la, enquanto eu, como não sei nada, também estou certo de não saber. Parece, pois, que eu seja mais sábio do que ele, nisso - ainda que seja pouca coisa: não acredito saber aquilo que não sei” (PLATÃO 2007. p. 62).

${ }^{34}$ Sobre a arqueologia do saber como poder e as práticas discursivas como estruturas possíveis de dominação, ver: FOUCAULT, 2008.
} 
Os conselhos aristotélicos ligam a economia e a política, oíkos e pólis em torno de uma relação de domínio, de posse. Ao mesmo tempo, distingue-se comandante e comandado, em torno do homem, que seria o cidadão que participaria da deliberação na pólis: "O escravo é completamente desprovido da faculdade de deliberar; a mulher a possui, mas débil e ineficaz; e a criança também a possui, mas nela a faculdade ainda é imperfeita, não está completamente desenvolvida" (ARISTÓTELES, 2010, p. 76). Há um nítido propósito de ligação e exclusão. Liga-se a política e a economia, excluindo-se alguns participantes de decisões econômicas importantes, do governo seja da oíkos e da pólis, ao argumento de que apenas os homens deteriam a virtude necessária:

[...]visto que cada família é uma parte da Cidade, e tais pessoas são as partes que constituem a família, e a virtude da parte está necessariamente em relação com o todo, é preciso que a educação das mulheres e das crianças se faça tendo em vista a constituição daquela Cidade (sua forma particular de governo), se as virtudes destes devem fazer alguma diferença na virtude das Cidades. E é claro que eles têm de fazer diferença: as crianças quando crescerem serão os cidadãos, e as mulheres perfazem a metade das pessoas livres da Cidade (ARISTÓTELES, 2010, p. 78).

A economia e a política são a arte de excluir e de se impor como projeto de poder. Não por outra razão, a política - e aqui acrescentaríamos a economia por ligação necessária é a guerra por outros meios, como diz Foucault, invertendo o aforismo de Carl von Clausewitz quando afirmou, no século XIX, que "a guerra não era mais do que a continuação da política". Para Foucault, "o poder político tem como função reinserir perpetuamente a relação de força, mediante uma espécie de guerra silenciosa, e de reinseri-la nas instituições, nas desigualdades econômicas, na linguagem, até nos corpos de uns e de outros" (FOUCAULT, 2002). Um poder que se reinsere nos indivíduos para perpetuar as desigualdades econômicas e controlar até mesmo o corpo, exercido através de instituições.

A lógica política se mistura com a lógica econômica em um só momento apropriante da vida dos indivíduos, uma soberania que marca e remarca nas relações econômicas, colocando cada qual em seu devido papel de subalternidade.

Para alcançar esse desiderato, a política se afirmou como ciência, eis que um saber detém legitimidade para controlar as relações econômicas. Primeiro, sobretudo, com Hobbes, em que a legitimidade da política está no estado de natureza da guerra de todos contra todos e que emerge a necessidade do uso da força e o dever de obediência à lei para que tal "guerra" seja controlada (HOBBES, 1998, p. 11-20). Mais uma vez a guerra, sempre ela, colocada como fundamento e, ao mesmo tempo, necessidade para se fazer política. 
Uma ideia que vai permear todo o desenvolvimento das relações de propriedade do século XVIII tal como encontrada em John Locke. Uma propriedade como vínculo entre uma pessoa e uma coisa, excluindo-se os demais. Vínculo que não prescinde das leis e do seu necessário dever de obediência (LOCKE, 2006, p. 50). Não há saída que não seja o egoísmo e o individualismo no pensamento político.

Essa mesma noção é que fascinou, por assim dizer, o desenvolvimento de projeto de poder totalitário cujo maior expoente foi Carl Schmitt. Um projeto de poder levado ao extremo da exclusão como prática econômica e também da biopolítica, um extremo de conservadorismo e política econômica mortal.

Extremo e limite duas palavras que ressignificam o sentido de soberania na teoria do decisionismo schmittiano. Para o autor, já em Bodin o significado de soberania é um caso limite, um caso extremo de decisão política fundamental. Conceito que se restringe aos limites, não está regulado pela ordem jurídica, dependendo apenas da vontade de quem decide, fundamento não fundamentado, limite não limitado. Um eterno retorno à Hobbes.

Em Schmitt (2009, p. 13), soberano é quem decide sobre o estado de exceção, em que somente essa definição pode ser justa com o conceito de soberania como um conceito limite. Conceito limite é o conceito da esfera mais extrema, vinculado ao caso mais extremo. Uma definição que não se deixa apropriar por nenhum limite sociológico ou jurídico. Definição, aliás, que está no centro do pensamento hobbesiano em que "Autoritas, non veritas facit legem": A autoridade, não a verdade, faz a lei, expresso no Leviatã (SCHMITT, 2009, p. 73).

Mas a soberania como decisão política está ancorada em um projeto teórico mais amplo de Carl Schmitt. Uma exceção não excepcional. Uma decisão sem decisão. Algo como uma necessidade desnecessária. Uma política sem homens feita não para eles, nem por eles, mas feita a partir de instituições, uma política do partizan. Uma política que contraria a democracia e coloca os interesses partidários e institucionais acima de qualquer valor ou interesse, sobretudo ligados à estrutura econômica.

A política tem como núcleo central o conceito de amigo-inimigo para o decisionismo de Schmitt (2015). Este é o caráter autônomo do político que perpassa os demais campos do agir humano como o estético, o econômico, o moral e o jurídico. O inimigo de Schmitt é sempre o inimigo público, não um indivíduo (liberal) incapaz de se produzir identidade e unidade. $\mathrm{O}$ inimigo produz conflito e até mesmo a guerra, o extermínio, pode ser fundamento do politico. Este é o conceito do político levado ao seu limite. Este 
conceito serve de critério metodológico para se determinar o adversário, é a essência do político e que determina as demais relações humanas.

Este estatuto epistemológico que alcança os conceitos de amigo/inimigo representa bem as condições de possibilidade para se pensar as situações limites e o alcance da filosofia política, em que todos os conceitos e ideias políticas estão dispostos a ganhar concretude/definição quando em situação extrema de antagonismo (FERREIRA, 2004).

Política e economia seguem a mesma lógica, uma lógica de determinação daqueles que devem ser excluídos e combatidos. A separação da filosofia política com o mundo da vida, com as relações sociais pretendida pela ciência foi nada mais do que um engodo, uma ficção para mascarar uma dominação/ imposição de privilégios históricos do homem sobre o próprio homem.

Essa história de dominação deve ser desmascarada. Para isso, a contribuição filosófica da dialética histórica de Hegel é importante, mas ganha um novo sentido com Marx. Tirar a mascara é compreender que a história é aquela de dominação do homem pelo homem. Isso passa, necessariamente, pela crítica que Marx faz à posição dos filósofos da teorética na décima primeira tese sobre Feuerbach de que "os filósofos se limitaram a interpretar o mundo de diferentes maneiras; o que importa é transformá-lo" (MARX, ENGELS, 2000, p.113). Essa transformação leva em consideração a práxis social.

Central no debate é a categoria de alienação em Marx que pretende desvendar as contradições presentes na sociedade em que cada plano constitui e realiza a alienação. No campo político, econômico, religioso a alienação produz sempre a mesma lógica, por isso é necessário elevar a contradição particular para a geral, isto é, analisar o processo de produção econômica na sociedade capitalista para, então, desconstruir o plano político como um todo. Mostrar as contradições históricas, eis o projeto de desconstrução de $\operatorname{Marx}^{35}$.

A economia capitalista nada mais faz do que pôr em movimento sem fundamento a ganância, o conflito, a guerra e a concorrência, assim como a política o faz. Para tanto, coloca como dado a propriedade privada, emergindo como lei sem fundamentar a origem entre trabalho e capital (MARX, 2008, p.79). Este fato dado é possibilitado pelas leis, pelo Estado, pela política como superestrutura do capital. Não sem razão, o Estado é o comitê gestor dos interesses da burguesia (MARX, ENGELS, 2000).

\footnotetext{
${ }^{35}$ Com a differánce derridiana que sempre reaparece neste trabalho à margem, deve-se pensar naquilo que as palavras podem significar e não no que elas de fato significam (DERRIDA, 1973).
} 
A questão central do projeto teórico-político de Marx é a alienação que o processo de produção propicia ao trabalhador em que este perde a própria essência do ser. Um fato econômico elucida toda a relação filosófica-política:

\begin{abstract}
O trabalhador se torna tanto mais pobre quanto mais riqueza produz, quanto mais a sua produção aumenta em poder e extensão. O trabalhador se torna uma mercadoria tão mais barata quanto mais mercadorias crias. Com a valorização do mundo das coisas (Sachenwelt) aumenta em proporção direta a desvalorização do mundo dos homens (Menschenwelt). O trabalho não produz somente mercadorias; ele produz a si mesmo e ao trabalhador como uma mercadoria, e isto na medida em que produz, de fato, mercadorias em geral (MARX, 2008, p. 80).
\end{abstract}

A questão da alienação só pode ser combatida com uma supressão da propriedade privada. A proscrição da propriedade privada e o sentido que ela constitui para as relações sociais constitui uma emancipação total do ser humanos (MARX, 2008, p.142).

Karl Marx não pretende transpor a ideia de propriedade privada para uma propriedade privada universal, ou seja, o comunismo que busca a eliminação da propriedade privada não pode pretender apenas passar de uma lógica indivual para a comunitária uma vez que, ainda assim, estar-se-ia comungando da mesma lógica de propriedade privada. Por isso, Karl Marx dirige críticas ao que ele chama de comunismo grosseiro em que se pretende a proscrição da propriedade privada transmutando-a para propriedade coletiva.

O comunismo de Marx, então, pretende a proscrição de toda e qualquer forma de propriedade. Pretende extinguir a forma de relação objetiva com objetos, ficando apenas a relação subjetiva e essencial. O retorno do homem para com o homem, dialeticamente (LIMA, 2015). A relação deve ser do eu para com o outro que, para tornar-se eu precisa do outro e, assim, perde-se o sentido histórico da propriedade, da economia, da política, enfim dos traços humanos.

\title{
30 pensamento político brasileiro, a política da austeridade e o fantasma de Marx
}

No Brasil há uma contraditória originária que permeia nossa história, tornando um cenário complexo pensar a relação entre política e economia. Um pensamento político e social notoriamente conservador e a tentativa de recepção de uma economia liberal provocam uma profusão peculiar de regime de poder com viés autoritário.

Um pensamento político conservador atravessa a independência até a república. Por exemplo, a república não nasce de um anseio popular e uma necessidade de modificação 
do status quo da política imperial, mas como ilustra o pensamento conservador de Oliveira Vianna (2004, p. 91):

Não havia tal generalização de sentimento republicano, quando se deu a queda do Império. Por essa época, como o demonstramos, o sentimento mais generalizado não era o da crença na República, mas sim o de descrença nas instituições monárquicas, tais como existiam na Carta e eram praticadas nos centros do governo; mas, o certo é que essa descrença na Monarquia não importava necessariamente a existência do sentimento contrário, de fé nas instituições republicanas.

Como bem ilustra Álvaro Ricardo de Souza Cruz (2004, p.210-211), os ideais republicanos eram um anseio fundamentalmente da elite. A grande influência do positivismo no Brasil, sem comparação com outros países da América, leva a uma leitura conservadora do liberalismo: este se manifesta no âmbito econômico, mas é, paradoxalmente, conservador quando aplicado à política ou a outras áreas (LOPES, 2011, p. 341-342).

Mesmo os pensadores político-sociais conhecidos como interpretes do Brasil do início do século XX, tal como Gilberto Freyre com Casa Grande e Senzala e Sobrados e Mucambos, Sérgio Buarque de Holanda com Raízes do Brasil, Roberto da Matta em Carnavais, malandros e heróis e mesmo Raymundo Faoro com o Donos do Poder na verdade escondem um projeto conservador que, ao interpretar a cultura brasileira e valorizar o projeto de uma sociologia da inautenticidade, acabam por escamotear o processo hegemônico de dominação de uma elite sobre a "ralé" (SOUZA, 2011, p. 42-43). Na verdade, há um habitus que cria e recria as condições de perpetuação da desigualdade com a participação cínica da intelectualidade brasileira (SOUZA, 2012).

Essas críticas são importantes para reinterpretarmos o pensamento político brasileiro, mesmo o do século XX, como marcadamente conservador e perpetuador do descaso com os indivíduos não privilegiados. Em verdade, como o pensamento político e as práticas políticas como um todo não existem autonomamente em relação aos interesses econômicos, como já denunciara Marx, o pensamento político brasileiro está a serviço de uma pequena elite econômica que, vez por outra, desfere seu ódio contra as políticas sociais de redistribuição de renda ou de melhoria nas condições de desigualdade presente de forma marcante na sociedade brasileira.

De fato, há um ódio à democracia presente no imaginário da elite econômica que, com medo de políticas sociais de redistribuição de renda, possam trazer um sopro de igualdade ao profundo déficit democrático brasileiro. 
Não é à toa, pois, que o golpe civil-militar de 1964 que afundou nosso país no mais longo período de ditadura e violência estatal tenha como pano de fundo o medo ao comunismo, mas cujo leitmotiv são os interesses econômicos de empresários que apoiaram a derrubada de João Goulart e implementar uma política desenvolvimentista que, de um modo ou outro, beneficiou a velha elite econômica ${ }^{36}$.

Mesmo aquele golpe já adviria da elítica econômica com interesses necessariamente egoístas e fincados na ideia de maior lucro individual.

Muito embora o texto constitucional de 1988 tenha sido emancipatório para grande parte da população, ainda manteve um abismo de desigualdade. Neste sentido, parcela da sociedade brasileira que conectamos diretamente ao empresariado que, em conjunto com os militares, conspiraram e efetivaram o golpe de Estado, também mantém um ódio ao processo democrático.

Essa mesma parcela, no entanto, embora tenha mudado o modus operandi, conspirou para o impedimento da Presidente eleita Dilma Rousseff com a mesma finalidade, romper com o processo de democratização e acesso de direitos para minorias alijadas historicamente do poder no Brasil.

Com um novo modo de atuar, agora através de um golpe provocado no parlamento, bem no local onde deveria atuar as vontades democráticas, o empresariado se embasa nos mesmos fundamentos, mas buscando implementar uma política de austeridade.

O golpe empresarial-parlamentar-midiático ocorrido em 2016 no Brasil, não à toa, fora comandado pela elite financeira, conforme concluiu o cientista político Jessé de Souza (2016, P.129). Mais do que um "velho acordão brasileiro" entre as diversas elites do país, o movimento golpista que deslegitimou e derrubou um governo democraticamente eleito, faz parte de uma onda política de cunho internacional encampada mundo afora após a grande crise de 2008. Tal política, também conhecida como austeridade, é altamente perniciosa, e dentre seus objetivos visa a proteger os verdadeiros causadores dessa crise, os bancos (BLYTH, 2013).

Ideia enraizada na base do liberalismo, a austeridade não é algo propriamente novo. Apesar de suas enormes inconsistências lógicas e fracassos empíricos, a política de austeridade sobreviveu ao longo desses muitos anos como uma espécie de ideia zumbi ${ }^{37}$ E

\footnotetext{
${ }^{36}$ Com uma construção histórica impressionante, o livro de Heloisa Starling (1986) é uma referência no tema.

37 Blyth chama atenção para a classificação de austeridade como uma ideia zumbi, porque a mesma foi repetidamente reprovada, mas continua a aparecer. O autor cita a obra de John Quiggin "Zombie Economics" (2013. p.29).
} 
desde o fim da década passada a pauta em defesa da austeridade ganhou forte fôlego e proeminência global.

No Brasil, percebe-se a entrada da austeridade com grande força a partir do segundo governo da presidenta Dilma Rousseff, em 2015, cujo episódio emblemático veio a ser a nomeação do então ministro da economia, Joaquim Levy.

Utilizando-se de ferramentas que demonizam o Estado, o movimento golpista de 2016, encabeçado pela elite financeira, apoiado pela mídia e pelo judiciário, marcou a história do Brasil como sendo um momento gravíssimo, pontuado aqui como crucial de rompimento das políticas sociais em curso até então, visto que a atual roupagem da austeridade implica a revisão do paradigma do Estado Social.

O apoio da mídia foi fundamental no golpe parlamentar ocorrido no Brasil em 2016. Os maiores veículos de comunicação se empenharam de maneira sistemática com o objetivo de desmoralizar o Partido dos Trabalhadores (PT), tentando provar ineficiência e descalabro dos governos progressistas no poder desde 2003, inclusive no que diz respeito aos seus programas sociais, responsáveis por retirar da miséria 40 milhões de brasileiros (GUIMARÃES, 2016).

Quanto ao poder judiciário, no âmbito da Lava Jato, nada fez para coibir a formação da opinião pública criada pela mídia no sentido de transformar determinados acusados, sequer julgados, em verdadeiros criminosos, que passaram a ser tratados nos noticiários das redes televisivas do Brasil e nos principais folhetins de mídia impressa como sujeitos já condenados judicialmente, antes mesmo do desenrolar daquilo que deveríamos chamar de devido processo legal.

Não se pode negar que o segundo governo Dilma optou "acender uma vela" para a cartilha dos seus opositores, regida pelo mercado financeiro, e deu início à política de austeridade em nosso país.

Em que pese essa opção de Dilma pelo programa de ajuste, a presidenta enfaticamente declarou que tais cortes não afetariam as conquistas dos trabalhadores (horário de trabalho, férias, aposentadoria, seguro desemprego etc.) nem os programas sociais. Mesmo flertando com o programa da oposição, numa clara sinalização de que poria em prática exigências liberalizantes, o mercado financeiro não se deu por satisfeito. A política ideológica de austeridade desse início do século XXI assenta-se sobre um pilar ortodoxo de que um governo não é capaz de se poupar ao ponto de resgatar a tal credibilidade se não impuser ao povo cortes permanentes nos direitos sociais. Daí a Ponte para o Futuro, o golpe de estado parlamentar e a instalação da perniciosa política de austeridade. 
Austeridade "é uma ideia perigosa" que destrói os Estados expostos à crise, assim defendeu Mark Blyth em seu livro “Austeridade - A história de uma ideia perigosa”. Nesta obra, o autor verifica, através de uma profunda pesquisa, que não há em escala mundial casos de crise que tenham sido solucionados com políticas de austeridade. Essa forma de deflação voluntária na qual a economia se ajusta através da redução de salários e de despesas públicas, de cortes no orçamento do Estado, com a finalidade de se restabelecer a competitividade, na verdade traz "políticas de classe, distúrbios, instabilidade política, mais dívidas, homicídios e guerra (BLYTH, 2013, P. 117).

O professor escocês de economia política recorre aos exemplos de Portugal, Itália, Grécia e Espanha, países que lançaram duros pacotes de austeridade desde o início da crise financeira de 2008 e demonstra que não foram alcançados os objetivos da tão esperada estabilidade dos países da zona do euro.

Fundamento desse problema está no engodo da proposta. A chamada "crise da dívida soberana", supostamente existente devido a um excessivo gasto por parte dos Estados, mas que na verdade as dívidas externas tiveram início com o sistema financeiro-bancário.

O que de fato ocorreu com esses países da zona do Euro, e se repete no Brasil, é uma crise dos mercados financeiros, que tem origem nos bancos, isto é, são problemas que, oriundos do setor privado, acabam por destruir o Estado Social.

É importante notar que o "mercado" é um ínfimo grupo de multimilionários investidores, especuladores e rentistas, jornalistas e articulistas de economia. A confiança desses "investidores" tem a ver com a oportunidade de investimentos lucrativos.

Mas destruir o Estado Social por quê? Porque impor austeridade aos sonegadores de impostos e acumuladores de grandes fortunas não é uma alternativa. Baixar impostos dos menos favorecidos e camadas médias, aumentando-os para aqueles com ampla capacidade de contribuição também não é uma alternativa. Não se cogita tão pouco baratear a inflação de alimentos com incentivos à agricultura familiar.

Há sim alternativas. O consumo público vinculado ao gasto social tem grande impacto sobre o crescimento, sobretudo com o aumento da progressividade tributária. Reavaliar experiências internacionais que proponham alterações no sistema tributário com o intuito de conciliar equilíbrio fiscal e redução das desigualdades são alternativas, dentre outras, a esse nefasto modelo de austeridade.

Ao contrário, a ditadura do mercado financeiro impõe mais privatizações, desburocratizações traduzidas no velho lema "menos lei e mais liberdade para o capital". 
Apesar de a austeridade ser atualmente o "espírito do tempo", com lemas de privações, corte de gastos, enxugamento da máquina pública, frisa-se aqui, ela não é a única alternativa. O sociólogo alemão Ulrick Beck, em sua obra "Europa Alemã" (2015) tem a seguinte opinião: "está na hora de virar o jogo: não precisamos mais de bailouts (injeções de liquidez) para os bancos, e sim de um mecanismo de salvação social para a Europa das pessoas, dos indivíduos".

As nações europeias também conhecidas como PIIGS (Portugal, Irlanda, Itália, Grécia e Espanha), capitaneadas pelas grandes agências financeiras mundiais (FMI e BCE, por exemplo), desde 2008 desenvolveram o pacto da austeridade. A defesa desse pacto fiscal está embasada na ideia de que a democracia de uma forma geral inevitavelmente resultará em decisões econômicas irracionais, como gastos públicos em excesso e o consequente aumento do endividamento. Obviamente, o aumento nos cortes dos gastos públicos afeta principalmente aqueles que mais dependem dos serviços e assistência pública.

E por que a democracia possui essa força irracional dominante? A resposta, parece-nos, estaria em Derrida, que ao falar dos Espectros de Marx, pontua a fala de Fukuyama, o qual noticia como uma "boa nova" o fato de "a democracia liberal permanecer como única aspiração política coerente que une diferentes regiões e culturas em volta da terra". Isso porque a propagação dessas ideias tenta estabilizar sua hegemonia às custas do "atestado de óbito" do Marxismo, como se "este cadáver" estivesse em decomposição em lugar seguro, longe de causar qualquer ameaça ao livre mercado, ao capital, ao liberalismo econômico.

Mas não! Derrida lembra-nos que ler, reler e discutir Marx é de alguma forma sempre desafiador, “à semelhança de uma coisa espectral” (DERRIDA, 1994, p. 35).

Aceitar o retorno de Marx, na forma de espectros, passaria por um decifrar, por um agir em direção a uma transformação que "modifique o mundo", aquilo que Marx denomina de "a revolução em permanência", como iminência e necessidade a termo. Derrida convoca-nos a uma tomada de posição na direção do porvir do "espírito" do Marxismo. Pois por mais que essa nova desordem, hoje intitulada de austeridade, seja forte o suficiente a se instalar, como o tem feito, não o bastante para denegar-se dos fantasmas de Marx.

Cabe a nós a responsabilidade de combater a conjuração sem precedentes àquilo que o Marxismo representa, fazendo uma real crítica da economia política, da existência da moeda como produção de ilusões, de aparências. Sem atacar o X da questão, não poderemos avançar rumo a um futuro focado na multiplicidade, na alteridade e na singularidade. Segundo afirma Derrida “é preciso analisar o próprio da propriedade, e como a propriedade (Eigentum) 
geral do dinheiro neutraliza, desencarna, priva de sua diferença toda propriedade (Eigentümlichkeit) pessoal.”. Para isso, temos que contar com a aparição fenomenal do espectro de Marx como um "desaparecido na aparição como reaparição do desaparecido" (DERRIDA, 1994, p. 21)

Conforme preceituado, a política de austeridade não é nova. Entretanto, nunca antes esteve posta tão sem amarras como no projeto atual. Sobrevivente e desnudada, tal política, em tese, aumenta a eficiência do Estado através do corte de gastos numa intensidade maior do que a redução de impostos. Portanto, não significa apenas dividir os prejuízos entre aqueles que não lhe deram causa, modo de concretização posto em modelos de austeridade outrora.

A face perversa da atual roupagem da austeridade é mais do que uma política economia; é a suspensão diuturna do Estado Democrático de Direito, utilizando-se no cenário sócio-jurídico, do paradoxo do permanente Estado de Exceção. A exemplo da promulgação da Emenda Constitucional número 95, em dezembro de 2016, suspende-se a Constituição Federal, entretanto, ela não deixa de estar em vigor. Um exemplo desse revés é que a partir da leitura do artigo 196 da CF, percebemos nitidamente o dito: a Emenda Constitucional do Teto dos Gastos acabou por produzir uma exceção no seio de nossa constituição. Referido artigo encontra-se formalmente em vigor, sem força-de-lei.

\section{A democracia radical e o engajamento político-social: sobre as condições para reconstrução democrática}

A solução para os problemas políticos atuais dentro desta quadra histórica não pode ser outra coisa que a própria política. À sombra dos interesses do capital sempre será um fato a ser levado em consideração em nosso país de pensamento político-conservador aliado à tentativa de um projeto econômico liberal. Esse cenário é que nos trouxe até este momento de graves impasses da democracia para falarmos com Avritzer (2016, p. 9) que identifica, em obra recente, cinco causas para o momento democrático vivido atualmente:

[...] [1] os limites do presidencialismo de coalizão, isto é, a deslegitimação da forma de fazer alianças, característica da democracia brasileira desde 1994; [2] os limites da participação popular na política, que tem crescido desde 1990 e é bem-vista pela população, mas não logra modificar sua relação com a representação; [3] os paradoxos do combate à corrupção, que avança e revela elementos dramáticos da privatização do setor público no país, os quais terminam por deslegitimar ainda mais o sistema político; [4] as consequências da perda de status das camadas médias que passaram a estar 
mais próximas das camadas populares a partir do reordenamento social provocado pela queda da desigualdade; por fim, [5] o novo papel do Poder Judiciário na política ${ }^{38}$.

Essa política de austeridade e os seus efeitos sociais deletérios implantados por interesses hegemônicos após o impedimento da Presidente Dilma Rousseff só poderá ter como contraposição um retorno ao político.

A questão não é a eliminação do poder e do conflito, mas é colocar a heterogeneidade, o múltiplo e o conflito em condições existenciais democráticas. Uma luta pela promoção dos valores democráticos em uma sociedade plural e a promoção de emancipação social para todos os integrantes. As práticas políticas liberais, muito embora desempenharam um importante papel, não conseguem compreender às novas formas políticas que aparecem em um Estado Democrático de Direito.

Nesta toada, é preciso adotar uma perspectiva de uma democracia plural e radical tal como a preconizada por Chantal Mouffe em que se aceita a existência do poder, mas procura delimitar que o projeto democrático é essencialmente aberto, permitindo o ingresso de todos os valores sociais e teria como pressuposto a aceitação de que não há nenhum fundamento absoluto e nada que não possa ser politizado, para demonstrar a violência que se oponha ao projeto democrático, cujos fundamentos reinariam na racionalidade e na objetividade (MOUFFE, 1996, p. 193).

Chantall Mouffe (2005) desenvolve um enfrentamento ao modelo consensualista de democracia deliberativa, criticando as escolas de Rawls e Habermas, oferecendo como alternativa a democracia agonística. Não obstante as críticas à alternativa proposta pela autora, estruturadas em afirmar que o modelo agonistíco não se trata de um modelo teórico estruturado, é importante o resgate da proposta da cientista política pós-marxista, considerando que o avanço da pesquisa científica e a produção de um novo conhecimento precisam integrar-se àqueles pré-existentes.

Ao contrário de um modelo democrático habermasiano em que a política deliberativa teria o condão de afastar o poder, a democracia radical aceita

que as relações de poder são constitutivas do social, então a questão principal da política democrática não é como eliminar o poder, mas como constituir formas de poder compatíveis com valores democráticos. Admitir a existência de relações de poder e a necessidade de transformá-las, enquanto se renuncia à ilusão de que poderíamos nos livrar completamente do poder, é a especificidade do projeto de democracia radical e plural (MOUFFE, 2003, p. 14).

\footnotetext{
${ }^{38}$ AVRITZER, Leonardo. Impasses da Democracia no Brasil. Rio de Janeiro: Civilização Brasileira, 2016. p. 9. 
A outra questão é romper com o essencialismo do sujeito político, permitindo ver como as diferenças se relacionam e como são construídos os projetos de subordinação e dominação. A constituição de um "nós" e "eles" só ganha sentido no sujeito concreto, não em um universalismo abstrato. Ademais, é nessa relação que se descobre que participa do nós e que são eles. Esse é o núcleo central de um modelo agonístico de democracia. Como operar com essa distinção de modo compatível com uma democracia radical.

Mouffe critica o consenso e o modelo agregativo de Joseph Schumpeter, expondo que nesse padrão o interesse das pessoas tem sido posto de lado, principalmente na estrutura dos partidos tradicionais. E acrescenta que o grande problema do modelo agregativo é o desencorajamento da participação popular na tomada de decisões. A avaliação de Chantal Mouffe é pertinente, há um continum entre a proposta de Schumpeter e o "espírito do tempo" chamado austeridade.

Como bem explica a autora,

No campo da política, a distinção da democracia radical pressupõe que o "outro" não seja visto como um inimigo a ser destruído, mas como um "adversário", isto é, alguém com cujas ideias iremos lutar, mas cujo direito de defender tais ideias não vamos questionar. Esta categoria de adversário não elimina o antagonismo, embora deva ser distinguida da noção liberal de competidor com a qual é às vezes identificada. Um adversário é um inimigo legítimo, um inimigo com quem temos em comum uma adesão partilhada aos princípios ético-políticos da democracia. Mas nossa divergência diz a respeito ao seu significado e implantação, e não é algo que poderia ser resolvido através de deliberação e discussão racional; daí o elemento antagonístico na relação. Aceitar a posição do adversário é experimentar uma mudança radical na identidade política. Isso tem mais a qualidade de uma conversão do que de uma persuasão racional (no mesmo sentido do argumento de Thomas Kuhn sobre a adesão a um novo paradigma científico como um tipo de conversão). Na verdade, acordos são possíveis. Eles são parte de um processo da política, mas deveriam ser vistos como reveses temporários numa confrontação em curso (MOUFFE, 2003, p. 16).

Para lidar com o ódio das elites, não é preciso uma posição moralizante, mas ainda mais democracia no sentido de conversão de inimigos em adversários. Aceitar as posições, mas o compartilhamento de que apenas a democracia restauraria um projeto perigoso de dominação. Se tal modelo for implementado em via dupla, aí teremos um engajamento político-social em torno da Constituição de 1988 e o tão almejado projeto democrático rompido no ano de 2016.

Os impasses da democracia no Brasil só poderão ter uma solução constitucionalmente legítima na medida no regresso do político e em uma prática política 
radical que leve em consideração a pluralidade de nossa sociedade e a possibilidade de colocar em evidência as diferenças sociais e demonstrar a violência social e econômica que impera em nosso país há séculos e séculos.

\section{Conclusão}

Há uma relação intrínseca entre política e economia. Mais do que uma relação de superestrutura e infraestrutura econômica, há uma imbricação no próprio conceito de economia e política que remonta a Grécia antiga. A política de austeridade se instaura em nosso país aliando-se a um pensamento político liberal e conservador. Através da cooptação democrático-política, os ideais da política de austeridade conseguem realizar, por meio de uma elite econômica e politicamente conservadora, uma ruptura político-institucional com o objetivo de destruição do projeto de Estado Social.

Tal política é incorporada de países europeus que adotaram um pacto pela austeridade. O pano de fundo europeu, na verdade, é o velho medo do fantasma de Marx. O projeto político neoliberal instaura um Estado de Exceção com um objetivo de dominação sobre a política que permite o implante de ideais hegemônicos liberalizantes para propiciar benefícios para uma minoria e interditar a discussão política.

O maior exemplo é a Emenda dos gastos público que provoca um desmonte no Estado Social, instaurando um estado de exceção político-econômico com a Constituição de 1988 em plena vigência. Privatizações, portanto, aparecem no seio da discussão política apenas como uma forma de permitir o ataque ao Estado Social.

A única forma de combate da política de austeridade e o estado de exceção econômico-financeiro é um regresso ao político. Deve-se encarar o poder tal qual ele é e procurar enfrentá-lo com uma democracia radical e entender que as opções políticas são sempre contingenciais, não existindo fórmula mágica para a resolução dos problemas econômico-financeiros que não seja uma solução propriamente democrática.

\section{Referências Bibliográficas}

ARISTÓTELES. Política. Trad. Pedro Constantin Tolens. $5^{\text {a }}$ ed. São Paulo: Martin Claret, 2010.

AVRITZER, Leonardo. Impasses da Democracia no Brasil. Rio de Janeiro: Civilização Brasileira, 2016. 
BLYTH, Mark. Austeridade:. A história de uma ideia perigosa.. Tradução Freitas e Silva. Lisboa: Editora Quetzal , 2013.

CRUZ, Álvaro Ricardo de Souza. A resposta correta: incursões jurídicas e filosóficas sobre as teorias da justiça. Belo Horizonte: Arraes editores, 2011.

CRUZ, Álvaro Ricardo de Souza. Breve histórico do Supremo Tribunal Federal e do controle de constitucionalidade brasileiro. In: SAMPAIO, José A. Leite (org.). Crise e desafios da Constituição. Belo Horizonte: Del Rey, 2004.

DERRIDA, Jacques. Espectros de Marx. Rio de Janeiro: Relume-Dumará, 1994.

DERRIDA, Jacques. Gramatologia. São Paulo: Perspectiva, 1973.

FERREIRA, Bernardo. O risco do político: crítica ao liberalismo e teoria política no pensamento de Carl Schmitt. Belo Horizonte: Editora da UFMG, 2004.

FOUCAULT, Michel. A arqueologia do saber. Rio de Janeiro: Forense Universitária, 2008.

FOUCAULT, Michel. Em defesa da sociedade - curso no Collège de France (1975-76). São Paulo: Martins Fontes, 2002.

GUIMARÃES. Samuel Pinheiro. Impeachment, Golpe de Estado e Ditadura de Mercado. In: A Resistência ao Golpe de 2016. $1^{\text {a }}$ ed. Bauru: Canal 6 editora, 2016.

HEIDEGGER, Martin. Ser e tempo. $6^{\text {a }}$ ed. Trad. Marcia de Sá Cavalcante Schuback. Petrópolis: Vozes, 2012.

HEIDEGGER, Martin. Introdução à metafísica. Rio de Janeiro: Tempo brasileiro, 1999.

HOBBES, Thomas. Prefácio ao leitor. Do cidadão. Trad. Renato Janine Ribeiro. $2^{\mathrm{a}}$ ed. São Paulo: Martins Fontes, 1998.

LIMA, Carlos Cirne. Dialética para principiantes. 6a ed. Porto Alegre: Escritos, 2015.

LOCKE, John. Segundo tratado sobre o governo. São Paulo: Martin Claret, 2006.

LOPES, José Reinaldo de Lima. O Direito na História. $3^{\text {a }}$ ed. SP: Atlas, 2011.

MARX, Karl e ENGELS, Friedrich. Manifesto do partido comunista. $2^{a}$ ed. São Paulo: Martin Claret, 2000.

MARX, Karl. Manuscritos econômicos-filosóficos. São Paulo: Boitempo, 2008.

MOUFFE, Chantal. Democracia, cidadania e a questão do pluralismo. Política \& Sociedade, Florianópolis, v. 1, n. 3, p. 11-26, out. 2003.

MOUFFE, Chantal. O regresso do político. Lisboa: Gradiva, 1996. 
MOUFFE, Chantal. Por um modelo agonístico de democracia. Dossiê Democracias e Autoritarismos. Social Política Curitiba, 25. p. 11-23, nov. 2005.

PLATÃO. Apologia de Sócrates. Tradução de Pietro Nassetti. São Paulo:

Editora Martin.Claret, 2007.

SCHMITT, Carl. Teología Política. Trad. Francisco Javier Conde. Madri: Trotta, 2009.

SCHMITT, Carl. O Conceito do Político. Edições 70: Lisboa, 2015.

SOUZA, Jessé de. A Radiografia do Golpe. Entenda como e porque você foi enganado. São Paulo: Leya Editora Leya, 2016.

SOUZA, Jessé. A construção social da subcidadania: para uma sociologia política da modernidade periférica. $2^{\mathrm{a}}$ ed. Belo Horizonte: Editora UFMG, 2012.

SOUZA, Jessé. A ralé brasileira: quem é e como vive. Belo Horizonte: Editora UFMG, 2011. p. $42-43$

STARLING, Heloisa Maria Murgel. Os senhores das gerais: os novos inconfidentes e o golpe de 1964. $4^{\text {a }}$ ed. Petropólis: Ed. Vozes, 1986.

VIANA, Oliveira. O ocaso do Império. Brasília: Edições do Senado Federal,2004.

Data de recebimento: 03.06.2020

Data de aprovação: 08.08.2020 